\title{
Formulasi Sediaan Krim Tabir Surya dari Ekstrak Etanol Buah Bisbul (Diospyros blancoi)
}

\section{(Sunscreen Cream Formulation of Bisbul fruit (Diospyros blancoi) Ethanol Extract)}

\author{
HARRY NOVIARDI ${ }^{1 *}$, DEVI RATNASARI², MUHAMMAD FERMADIANTO ${ }^{1}$ \\ ${ }^{1}$ Program Studi S1 Farmasi, Sekolah Tinggi Teknologi Industri dan Farmasi Bogor, Bogor, 16151 \\ ${ }^{2}$ Program Studi Farmasi, Fakultas Ilmu Kesehatan, Universitas Singaperbangsa Karawang, \\ Karawang, 41361 \\ *Penulis korespondensi, Hp : 0251-8323819 \\ e-mail: harry.noviardi@sttif.ac.id
}

Diterima 17 September 2019, Disetujui 28 Oktober 2019

\begin{abstract}
Abstrak: Buah bisbul merupakan salah satu tanaman tropis yang tumbuh di Indonesia. Kandungan fitokimia buah bisbul antara lain golongan senyawa alkaloid, tanin, flavonoid, dan fenolik. Golongan senyawa flavonoid dan fenolik berpotensi sebagai antioksidan. Antioksidan dapat menghambat proses kerusakan sel kulit akibat oksidasi. Penelitian ini bertujuan untuk membuat krim tabir surya yang optimum, sesuai mutu, stabilitas, dan memiliki khasiat sebagai tabir surya yang berbahan dasar buah bisbul (Diospyros blancoi). Sampel yang digunakan dalam penelitian ini adalah buah bisbul setengah matang yang dibuat menjadi ekstrak kental. Ekstraksi dilakukan dengan metode maserasi menggunakan pelarut etanol 95\%. Hasil rendemen ekstrak yang diperoleh sebesar 12\%. Selanjutnya, dibuat menjadi sediaan krim tabir surya dengan konsentrasi 10, 20, dan 40\%. Krim yang telah dibuat, kemudian dievaluasi kualitas krim meliputi uji organoleptik, uji $\mathrm{pH}$, daya lekat, daya sebar, viskositas, stabilitas, dan nilai Sun Protection Factor (SPF). Berdasarkan pada hasil penelitian, ekstrak buah bisbul dapat dibuat menjadi sediaan krim tabir surya. Nilai SPF yang diperoleh dari konsentrasi ekstrak 10, 20, dan $40 \%$ secara berturut-turut adalah 9,25; 10,02; dan 13,00. Pada penelitian ini dapat disimpulkan bahwa formula dengan konsentrasi $40 \%$ merupakan krim terbaik yang memiliki nilai SPF tertinggi sebesar dengan proteksi kategori maksimal.
\end{abstract}

Kata kunci: Buah bisbul (Diospyros blancoi), krim, SPF, tabir surya.

\begin{abstract}
Bisbul fruit is one of the tropical plants that grows in Indonesia. Phytochemical contents of bisbul fruit are alkaloids, tannins, flavonoids, and phenolic compounds. Flavonoids and phenolic compounds are potentially as antioxidants. Antioxidants could inhibit skin cell damage due to oxidation process. This study aimed to make the optimum sunscreen cream, based on quality, stability, and activity as a sunscreen from bisbul fruit (Diospyros blancoi). The sample used in this research was bisbul, which made into extract. The extraction was done by a maceration method using $95 \%$ ethanol solvent. The results showed that extract yield obtained was $12 \%$. Furthermore, made into a sunscreen cream preparation with concentrations of 10,20 , and $40 \%$. The cream had been made, then was evaluated the quality organoleptic test, $\mathrm{pH}$, adhesiveness, dispersive power, viscosity, stability, and the Sun Protection Factor (SPF) value. The results showed that of bisbul extract could be made into a sunscreen cream. The SPF value obtained from the extract concentration of 10,20 , and $40 \%$ consecutively were $9.25,10.02$, and 13.00 . Furthermore, it could be concluded that the formula with a concentration of $40 \%$ was the best quality of the cream and the highest SPF value of 13.00 with maximum protection.
\end{abstract}

Keywords: Bisbul fruit (Diospyros blancoi), cream, SPF, sunscreen. 


\section{PENDAHULUAN}

INDONESIA merupakan negara beriklim tropis yang memiliki paparan sinar matahari yang tinggi ${ }^{(1)}$. Radiasi sinar matahari terdiri atas sinar inframerah $(>760 \mathrm{~nm})$, sinar tampak (400-760 nm), dan sinar UV (ultraviolet) yang terdiri atas UV A (320-400 nm), UV B (290- 320 nm) serta UV C (200-290 nm). Sinar matahari yang sampai di permukaan bumi dan mempunyai dampak negatif kerusakan terhadap kulit adalah sinar UV A dan UV B, sedangkan UV C tertahan karena diabsorbsi seluruhnya oleh lapisan ozon sehingga tidak mencapai permukaan bumi ${ }^{(2)}$.

Paparan sinar matahari selain memberikan efek menguntungkan juga memberikan efek merugikan pada tubuh manusia bergantung pada panjang dan frekuensi paparan, intensitas sinar matahari, dan sensitivitas individu yang terpapar ${ }^{(3)}$. Paparan sinar UV yang berlebihan dapat mengakibatkan sunburn, eritema, hiperpigmentasi, penuaan dini, bahkan kanker kulit. Untuk mencegah efek merugikan tersebut, dapat dilakukan beberapa cara, salah satunya adalah pemakaian tabir surya ${ }^{(4)}$. Tabir surya (sunscreen) adalah bahan yang dapat mengabsorbsi, memantulkan, atau menghamburkan radiasi UV sehingga dapat menjaga kulit dari efek UV yang membahayakan ${ }^{(5)}$.

Antioksidan merupakan senyawa pemberi elektron, dapat meredam radikal bebas dan Reactive Oxygen Species ${ }^{(6)}$. Penggunaan antioksidan pada sediaan tabir surya dapat meningkatkan aktivitas fotoprotektif dan dapat mencegah berbagai penyakit yang ditimbulkan oleh radiasi sinar ultraviolet. Adapun beberapa senyawa aktif antioksidan seperti flavonoid, tanin, antrakuinon, sinamat, vitamin $\mathrm{C}$, vitamin $\mathrm{E}$, dan betakaroten telah dilaporkan memiliki kemampuan sebagai pelindung terhadap sinar ultraviolet ${ }^{(7)}$. Berdasarkan pada penelitian Widowati et al. (2005) salah satu tanaman yang mempunyai efek antioksidan adalah buah bisbul (Diospyros blancoi) ${ }^{(6)}$.

Senyawa fenolik khususnya golongan flavonoid mempunyai potensi sebagai tabir surya karena adanya gugus kromofor (ikatan rangkap tunggal terkonjugasi) yang mampu menyerap sinar UV, baik UV A maupun UV B sehingga mengurangi intensitasnya pada kulit. Efektivitas sediaan krim tabir surya berdasarkan pada penentuan nilai Sun Protection Factor (SPF) yang menggambarkan kemampuan tabir surya dalam melindungi kulit dari eritema.

Tabir surya dapat dibuat dalam berbagai sediaan farmasi salah satunya adalah sediaan krim. Krim adalah bentuk sediaan setengah padat mengandung satu atau lebih bahan obat terlarut atau terdispersi dalam bahan dasar yang sesuai ${ }^{(8)}$. Tipe krim dibedakan menjadi dua tipe, yaitu krim tipe minyak dalam air
$(\mathrm{M} / \mathrm{A})$ dan air dalam minyak $(\mathrm{A} / \mathrm{M})^{(9)}$. Krim tipe $\mathrm{M} / \mathrm{A}$ (vanishing cream) mudah dicuci dengan air, jika digunakan pada kulit, maka akan terjadi penguapan dan peningkatan konsentrasi dari suatu obat yang larut dalam air, sehingga mendorong penyerapannya ke dalam jaringan kulit. Sedangkan krim tipe A/M memiliki daerah sebaran lebih baik dan rasa panas minimal pada kulit ${ }^{(2)}$.

Berdasarkan pada uraian di atas, maka dilakukan penelitian dengan membuat formulasi sediaan krim tabir surya dari ekstrak etanol buah bisbul (Diospyros blancoi) dengan tiga konsentrasi yang berbeda (10, 20, dan 40\%) untuk menentukan formulasi yang terbaik dari evaluasi fisik dan nilai SPF. Konsentrasi ekstrak dibuat berdasarkan pada penelitian Juwita (2013) yang telah dimodifikasi ${ }^{(10)}$. Tujuan dari penelitian ini untuk mengetahui konsentrasi ekstrak buah bisbul yang paling optimum sebagai tabir surya berdasarkan pada penentuan nilai Sun Protection Factor (SPF) menggunakan spektrofotometer UV-Vis. Pada penelitian ini tipe krim yang digunakan dalam formulasi adalah tipe $\mathrm{A} / \mathrm{M}$ sebagai basis karena lebih lama melekat di kulit dan dapat melembutkan kulit.

\section{BAHAN DAN METODE}

BAHAN. Bahan yang digunakan dalam penelitian ini adalah buah bisbul (Diospyros blancoi A.DC) didapat dari Jl. Pemuda Kota Bogor, Etanol 95\%, sorbitan monostearat (PT.Brataco), trietanolamin (TEA), cera alba (PT.Brataco), metil paraben (PT.Brataco), propil paraben (PT.Brataco), parafin cair (PT. Brataco), aquades, vitamin $\mathrm{C}, 1,1$ - difenil-2-pikrilhidrazil (DPPH), pereaksi Bouchardat, Dragendrof, asam klorida $2 \mathrm{~N}$, ammonia $\mathrm{P}$, eter $\mathrm{P}$, kloroform $\mathrm{P}$, natrium sulfat anhidrat $\mathrm{P}$, metanol $\mathrm{P}$, magnesium $\mathrm{P}$, asam klorida $\mathrm{P}$, larutan $\mathrm{FeCl}_{3} 1 \%$.

Alat. Alat yang digunakan dalam penelitian ini adalah peralatan gelas, neraca digital Acis AD-300i, sudip, oven (Memmert), pH meter, pipet tetes, kaca preparat, penangas air, rotary evaporator (Ika) RV 10, lumpang dan alu, viskometer brookfield MLVT 115, cawan porselin, spektrofotometer UV-vis (Shimadzu) UV mini-1240V, dan Elisa reader Epoch 2, blender (Miyako) B1-152 Gf, mixer (Maspion), alumunium foil, desikator, sentrifugator 80-2.

METODE. Pembuatan Serbuk Simplisia. Buah bisbul setengah matang dibersihkan dan daging buah dipisahkan dari biji dan kulit buahnya. Daging buah dipotong kecil-kecil sebanyak $2,5 \mathrm{~kg}$. Kemudian dikeringkan menggunakan oven pada suhu $40{ }^{\circ} \mathrm{C}$ sampai simplisia kering. Setelah itu diserbukkan menggunakan blender Miyako BL-152 GF lalu diayak 
menggunakan ayakan ukuran 40 mesh $^{(3,10)}$. Simplisia selanjutnya ditentukan kadar air dan komposisi fitokimianya.

Pembuatan Ekstrak Kental. Serbuk kering buah bisbul dimaserasi menggunakan etanol 95\%, dengan cara merendam satu bagian serbuk dengan 10 bagian pelarut. Perendaman dilakukan selama 6 jam pertama sambil sekali-sekali diaduk. Simplisia didiamkan selama 18 jam dan disaring menggunakan kain saring. Hasil filtrat dipisahkan dan ampasnya di remaserasi selama 2 hari menggunakan pelarut yang sama. Filtrat hasil remaserasi digabungkan dengan hasil filtrat maserasi yang pertama. Kemudian dipekatkan menggunakan rotary vacum evaporator pada suhu $60{ }^{\circ} \mathrm{C}$ sampai pelarut habis menguap ${ }^{(11)}$. Setelah mendapatkan ekstrak kental, dihitung rendemen ekstrak total.

Uji Antioksidan Ekstrak Kental Buah Bisbul ${ }^{(12)}$. Metode yang digunakan untuk menganalisis daya antioksidan adalah metode DPPH (1,1- difenil-2pikrilhidrazil). Uji DPPH berdasarkan pada pengukuran penentuan absorbsi DPPH pada panjang maksimum 514-517 nm menggunakan spektrofotometer UV-Vis Elisa Reader Epoch 2. Aktivitas dinyatakan dengan konsentrasi efektif yang mampu meredam radikal bebas sebesar $50 \%$.

Pembuatan Larutan Stok DPPH $125 \boldsymbol{\mu M}$. Sebanyak 4,9 mg DPPH (BM 394,32 gram/ mol) dimasukkan ke dalam labu ukur, kemudian ditambahkan etanol pro analisis sampai $100 \mathrm{~mL}$. Untuk mencegah terkena sinar matahari, labu ukur dilapisi alumunium foil dan larutan diletakkan di tempat gelap.

Preparasi Sampel dan Vitamin C. Sebanyak $10 \mathrm{mg}$ sampel dan $10 \mathrm{mg}$ vitamin $\mathrm{C}$ masing-masing dilarutkan dengan DMSO sebanyak $1 \mathrm{~mL}$ di dalam tabung reaksi yang berbeda. Selanjutnya, disonikasi hingga larut dan divorteks agar larutan homogen. Untuk deret konsentrasi sampel, yaitu 19,53; 39,06; 78,$12 ; 156,24$; dan $312,48 \mathrm{bpj}$, sedangkan untuk vitamin $\mathrm{C}$ deret konsentrasinya yaitu, 1,$25 ; 2,5 ; 5$; 10; dan 20 bpj.

Pengukuran Sampel dan Vitamin C. Sebanyak $100 \mu \mathrm{L}$ sampel dan vitamin $\mathrm{C}$ dimasukkan ke dalam microplate dilakukan sebanyak dua kali pengulangan. Untuk ulangan 1 dan 2 ditambahkan DPPH sebanyak $100 \mu \mathrm{L}$, sedangkan untuk kontrol negatif hanya ditambahkan etanol 95\% sebanyak $100 \mu \mathrm{L}$. Inkubasi dilakukan pada suhu ruang dengan kondisi gelap selama 30 menit. Larutan diukur di alat Elisa Reader pada panjang gelombang $517 \mathrm{~nm}$.

Pembuatan Formula Sediaan Krim. Pada pembuatan sediaan krim, langkah yang pertama dilakukan adalah pembuatan basis krim dengan cara fase minyak (cera alba, Parafin cair, sorbitan monostearat) dipanaskan pada suhu $70{ }^{\circ} \mathrm{C}$ dalam penangas air. Setelah melebur semua ditambahkan propil paraben. Selanjutnya, dilarutkan trietanolamin dengan air panas dalam cawan porselin yang berbeda, setelah larut semua ditambahkan metil paraben. Fase air dalam keadaan panas dimasukkan ke dalam fase minyak sedikit demi sedikit dan diaduk dengan mixer sampai terbentuk basis krim. Campuran fase minyak dan air ditambahkan ekstrak buah bisbul dan diaduk sampai homogen. Konsentrasi ekstrak etanol 95\% buah bisbul yang digunakan setiap $20 \mathrm{~g}$, yaitu 2, 4, dan 8 g. Krim yang terbentuk dimasukkan ke dalam pot krim. Formula yang digunakan dapat dilihat pada Tabel $1^{(10)}$.

Tabel 1. Formula krim ekstrak etanol buah bisbul ${ }^{(10)}$.

\begin{tabular}{lccc}
\hline \multicolumn{1}{c}{ Bahan } & $\begin{array}{c}\text { F1 } \\
\text { (gram) }\end{array}$ & $\begin{array}{c}\text { F2 } \\
\text { (gram) }\end{array}$ & $\begin{array}{c}\text { F3 } \\
\text { (gram) }\end{array}$ \\
\hline Ekstrak buah bisbul & 2,00 & 4,00 & 8,00 \\
Cera alba & 2,70 & 2,40 & 1,80 \\
Nipagin & 0,20 & 0,20 & 0,20 \\
Nipasol & 0,02 & 0,02 & 0,02 \\
Parafin cair & 9,00 & 8,00 & 6,00 \\
Sorbitan monostearat & 0,36 & 0,32 & 0,24 \\
Trietanolamin & 0,54 & 0,48 & 0,36 \\
Aquades ad & 20,00 & 20,00 & 20,00 \\
\hline
\end{tabular}

Pemeriksaan Organoleptik. Pemeriksaan pemerian sediaan krim tabir surya terdiri atas Pemeriksaan warna, aroma, dan tekstur ${ }^{(13,14)}$.

Homogenitas. Pemeriksaan homogenitas dilakukan dengan cara: sediaan ditimbang $0,1 \mathrm{~g}$ kemudian dioleskan secara merata dan tipis pada kaca arloji. Krim harus menunjukkan susunan yang homogen dan tidak terlihat adanya bintik-bintik ${ }^{(13,14)}$.

Pemeriksaan pH Krim. Pemeriksaan dilakukan dengan menggunakan alat $\mathrm{pH}$ meter. Alat tersebut dikalibrasi terlebih dahulu sebelum digunakan. Kalibrasi dilakukan dengan menggunakan larutan dapar $\mathrm{pH} 4$ dan 10. Pemeriksaan $\mathrm{pH}$ dilakukan dengan mencelupkan elektroda ke dalam 1 gram sediaan krim yang diencerkan dengan air suling hingga $10 \mathrm{~mL}^{(13,14)}$.

Uji Daya Sebar. Sebanyak 0,1 gram krim ditimbang dan diletakkan ditengah-tengah kaca bulat. Kemudian kaca penutup ditimbang dan diletakkan di atas krim dan didiamkan selama satu menit dan diukur diameter krim yang menyebar. Selanjutnya, ditambahkan beban seberat 50 gram di atas kaca penutup dan dibiarkan selama satu menit, lalu dicatat diameter krim yang menyebar. Percobaan dilanjutkan dengan beban seberat 100, 150, dan 200 gram $^{(15)}$.

Uji Daya Lekat. Uji daya lekat menggunakan dua buah kaca transparan yang pada salah satu ujung 
kaca transparan ditekan beban 50 g selama 5 menit, melepaskan beban seberat $20 \mathrm{~g}$ dan dicatat waktunya hingga kedua objek tersebut terlepas. Pengujian dilakukan pada hari ke-0 dan hari ke-21. Adapun syarat waktu daya lekat yang baik adalah tidak kurang dari $4 \operatorname{detik}^{(16)}$.

Uji Viskositas. Viskositas dilakukan dengan menggunakan viskometer Brookfield, yaitu dengan memasang spindel No.4 pada alat. Kemudian, dicelupkan ke dalam sediaan sampai batas tertentu dan atur kecepatan $30 \mathrm{rpm}$ pada suhu $\left(25^{\circ} \mathrm{C}\right)$. Tiap masingmasing pengukuran dibaca skalanya (dial reading) ketika jarum merah telah stabil. Nilai viskositas dalam sentipoise (cps) diperoleh dari hasil perkalian dial reading dengan faktor koreksi untuk masing-masing spindel $^{(17,18)}$.

Uji Stabilitas. Penyimpanan Pada Suhu Rendah. Sampel krim ekstrak buah bisbul disimpan pada suhu rendah $\left(4 \pm 2{ }^{\circ} \mathrm{C}\right)$ selama 28 hari. Kemudian dilakukan pengamatan organoleptik (perubahan warna, aroma, homogenitas), serta pengukuran $\mathrm{pH}$ dengan pengamatan dilakukan setiap minggu selama 4 minggu $^{(19)}$. Pengukuran viskositas dilakukan pada hari ke-0 dan hari ke-21 $1^{(20)}$.

Penyimpanan Pada Suhu Kamar. Sampel krim ekstrak buah bisbul disimpan pada suhu kamar $\left(28 \pm 2^{\circ} \mathrm{C}\right)$ selama 28 hari, kemudian dilakukan pengamatan organoleptik (perubahan warna, aroma, homogenitas), serta pengukuran $\mathrm{pH}$ dengan pengamatan dilakukan setiap minggu selama 4 minggu ${ }^{(19)}$. Pengukuran viskositas dilakukan pada hari ke-0 dan hari ke-21 $1^{(20)}$.

Penyimpanan Pada Suhu Tinggi. Sampel krim ekstrak buah bisbul disimpan pada suhu tinggi $\left(40 \pm 2^{\circ} \mathrm{C}\right)$ selama 28 hari. Kemudian, dilakukan pengamatan organoleptik (perubahan warna, aroma, homogenitas), serta pengukuran $\mathrm{pH}$ dengan pengamatan dilakukan setiap minggu selama 4 minggu $^{(19)}$. Pengukuran viskositas dilakukan pada hari ke-0 dan hari ke-21(20).

Cycling Test. Sampel krim ekstrak buah bisbul disimpan pada suhu rendah $\left(4 \pm 2{ }^{\circ} \mathrm{C}\right)$ selama 24 jam, lalu dipindahkan ke oven suhu $40^{\circ} \mathrm{C}$ selama 24 jam, perlakuan ini adalah satu siklus. Percobaan diulang selama 6 siklus dan diamati adanya perubahan kondisi fisik krim (perubahan warna, bau, homogenitas) dibandingkan setelah percobaan dan sebelum percobaan $^{(21)}$.

Uji Sentrifugasi. Sampel krim ekstrak buah bisbul dimasukkan ke dalam tabung sentrifugasi. Kemudian, dimasukkan ke dalam sentrifugator dengan kecepatan putaran $3750 \mathrm{rpm}$ selama 5 jam. Hasil penelitian tersebut ekuivalen dengan efek gravitasi selama satu tahun, kondisi fisik krim dibandingkan setelah percobaan dan sebelum percobaan ${ }^{(21)}$.
Penentuan Nilai SPF. Sebanyak 0,1 gram masing-masing krim ekstrak buah bisbul (F1, F2, dan F3) dilarutkan dalam etanol $96 \%$ sebanyak $25 \mathrm{~mL}$, dicampur hingga homogen. Penentuan efektivitas tabir surya dilakukan dengan menentukan nilai SPF secara in vitro dengan alat spektrofotometer UVVis. Krim ekstrak buah bisbul di encerkan sampai 4000 bpj. Sebelumnya spektrofotometer dikalibrasi dengan menggunakan etanol $96 \%$ dimasukkan dalam spektrofotometer UV-Vis untuk proses kalibrasi ${ }^{(22)}$. Kemudian dibuat kurva serapan uji dalam kuvet pada panjang gelombang antara $290-320 \mathrm{~nm}$ dengan interval $5 \mathrm{~nm}$ menggunakan etanol $96 \%$ sebagai blangko. Kemudian hasil absorbansi dicatat dan dihitung nilai SPFnya ${ }^{(1,23-25)}$. Untuk menghitung nilai SPF digunakan rumus:

$$
\operatorname{SPF}=\operatorname{CFX} \sum_{290}^{320} \operatorname{EE}(\lambda) \mathrm{XI}(\lambda) \mathrm{XAbs}(\lambda)
$$

Keterangan:

$\mathrm{EE}=$ Spektrum efek eritema

I $=$ Spektrum intensitas sinar (Tabel 2)

Abs $=$ Absorbansi

$\mathrm{CF}=$ Faktor koreksi

Tabel 2. Nilai EE X I pada panjang gelombang 290-320 nm.

\begin{tabular}{cc}
\hline Panjang gelombang $(\lambda \mathrm{nm})$ & Nilai EE x I \\
\hline 290 & 0,0150 \\
295 & 0.0817 \\
300 & 0,2874 \\
305 & 0,3278 \\
310 & 0,1864 \\
315 & 0,0839 \\
320 & 0,0180 \\
\hline Total & 1,0000 \\
\hline
\end{tabular}

Analisis Data. Pada penelitian ini data yang diperoleh dilakukan analisis data menggunakan uji anova SPSS 16.0 dengan tingkat kepercayaan 95\%. Data yang dianalisis yaitu nilai SPF, daya sebar, daya lekat, dan viskositas krim.

\section{HASIL DAN PEMBAHASAN}

Karakteristik Simplisia Buah Bisbul. Buah bisbul yang digunakan dalam penelitian ini adalah buah bisbul jenis Diospyros blancoi A.DC / Diospyros discolor Willd, suku ebenaceae. Serbuk simplisia yang didapat sebanyak $1150 \mathrm{mg}$ dari $\pm 2,5 \mathrm{~kg}$ daging buah bisbul (tanpa biji dan kulit buah). Serbuk buah bisbul berwarna kuning kecoklatan, beraroma khas bisbul, dan tidak berasa. Simplisia dinilai cukup aman dan baik bila mempunyai kadar air kurang dari $10 \%{ }^{(26)}$ karena bila lebih dari $10 \%$ simplisia akan mudah 
ditumbuhi jamur dan menjadi rusak sehingga tidak dapat digunakan. Hasil kadar air diperoleh sebesar $8,05 \%$, hasil tersebut sesuai dengan literatur. Hasil uji fitokimia dapat dilihat pada Tabel 3 .

Tabel 3. Hasil uji fitokimia serbuk buah bisbul.

\begin{tabular}{lcc}
\hline \multicolumn{1}{c}{ Pengujian } & Hasil \\
\hline \multirow{2}{*}{ Alkaloid } & Bouchardat & + \\
& Dragendorf & + \\
Saponin & & + \\
Tanin & + \\
Fenolik & + \\
Flavonoid & + \\
Triterpenoid & + \\
Steroid & - \\
Glikosida & + \\
\hline
\end{tabular}

Rendemen Ekstraksi Buah Bisbul. Ekstraksi serbuk buah bisbul menggunakan metode maserasi. Ekstraksi dilakukan selama 3 × 24 jam sesekali diaduk menggunakan pelarut etanol 95\%. Hasil ekstraksi serbuk bisbul berupa ekstrak kental berwarna coklat kekuningan, beraroma khas bisbul, dan memiliki nilai $\mathrm{pH} 3$ karena memiliki kandungan flavonoid dan fenolik yang bersifat asam. Serbuk simplisia yang diekstrak sebanyak 995 gram dan diperoleh ekstrak sebanyak 119,3 gram sehingga diperoleh rendemen sebesar $12 \%$. Pemilihan pelarut berdasarkan pada keamanan dan kemudahan menguap dari pelarut sehingga dalam penelitian ini digunakan etanol 95\% sebagai pelarut. Etanol 95\% dipilih sebagai pelarut karena lebih efektif menarik metabolit sekunder khususnya flavonoid dan tanin yang berguna sebagai antioksidan dan tabir surya ${ }^{(27)}$.

Aktivitas Antioksidan Ekstrak Kental dan Krim Ekstrak Buah Bisbul. Penentuan antioksidan dilakukan dengan metode DPPH. Metode ini dipilih karena prosedur pengukuran antioksidan yang mudah dan dapat dilakukan dalam waktu yang singkat. Uji peredaman warna radikal bebas DPPH merupakan uji untuk menentukan aktivitas antioksidan dalam sampel yang akan diujikan dengan melihat kemampuannya dalam menangkal radikal bebas DPPH. Perubahan warna yang diamati dari larutan yang berwarna ungu menjadi warna kuning ${ }^{(28)}$. Pengukuran dilakukan dengan menggunakan spektrofotometri UV-Vis Elisa Reader Epoch 2 dengan panjang gelombang $517 \mathrm{~nm}$. Besarnya aktivitas antioksidan ditandai dengan nilai $\mathrm{IC}_{50}$. Nilai $\mathrm{IC}_{50}$ merupakan konsentrasi sampel yang dapat meredam DPPH sebanyak 50\%. Semakin kecil nilai $\mathrm{IC}_{50}$ berarti semakin tinggi aktivitas antioksidan. Hasil Pengujian aktivitas antioksidan dapat dilihat pada Tabel 4.
Tabel 4. Hasil uji antioksidan.

\begin{tabular}{ccc}
\hline Sampel & Nilai $^{\mathrm{IC}_{50}(\mathrm{ppm})}$ & Kategori $^{(12)}$ \\
\hline F1 & 4802,63 & Lemah \\
F2 & 3510,11 & Lemah \\
F3 & 638,32 & Lemah \\
Ekstrak & 69,13 & Kuat \\
Vitamin C & 4,31 & Sangat kuat \\
\hline
\end{tabular}

Berdasarkan pada hasil uji aktivitas antioksidan ketiga formulasi memiliki aktivitas antioksidan kategori lemah. Hasil pengujian menunjukkan F3 memiliki nilai aktivitas antioksidan lebih baik dibandingkan $\mathrm{F} 2$ dan $\mathrm{F} 1$, hal ini ditunjukkan dengan nilai $\mathrm{IC}_{50} \mathrm{~F} 3$, yaitu sebesar 638,32 sedangkan $\mathrm{F} 1$ sebesar 3510,11 dan F2 sebesar 4802,63. Pada F3 konsentrasi ekstrak buah bisbul yang ditambahkan ke dalam basis krim sebesar 40\% lebih banyak dibandingkan F1 dan F2. Nilai IC $_{50}$ ekstrak sebesar 69,13 bpj dan aktivitas antioksidannya lebih kuat dibanding yang telah dibuat sediaan. Aktivitas antioksidan setelah dibuat sediaan menjadi lebih lemah karena kemungkinan terjadi reaksi antara ekstrak dengan salah satu komponen dalam sediaan krim, sehingga aktivitas antioksidan sediaan lebih kecil dari ekstrak. Vitamin C sebagai pembanding memiliki nilai $\mathrm{IC}_{50}$ sebesar 4,31 yang termasuk kategori sangat kuat.

Hasil Evaluasi Fisik Sediaan Krim. Pemeriksaan organoleptik. Pemeriksaan organoleptik krim meliputi pemeriksaan warna, aroma, tekstur. hasil pemeriksaan organoleptik dapat dilihat pada Tabel 5.

Tabel 5. Hasil pemeriksaan organoleptik krim.

\begin{tabular}{llll}
\hline Krim & Warna & Aroma & Tekstur \\
\hline F1 & Krem & + & Lembut \\
F2 & $\begin{array}{l}\text { Coklat } \\
\text { muda }\end{array}$ & ++ & Lembut \\
F3 & Coklat tua & +++ & Lembut \\
Basis krim & Putih susu & - & Lembut \\
\hline Keterangan: & & \\
+ & $=$ Khas bisbul lemah & \\
++ & $=$ Khas bisbul sedang & \\
+++ & $=$ Khas bisbul kuat & \\
- & & $=$ Tidak beraroma &
\end{tabular}

Berdasarkan pada pemeriksaan yang telah dilakukan warna pada setiap formulasi berbeda F1 memiliki warna krem, F2 memiliki warna coklat muda, dan F3 memiliki warna coklat tua. Warna kecoklatan dari sediaan diakibatkan oleh penambahan ekstrak etanol buah bisbul yang berwarna coklat kekuningan. Hal ini dibuktikan sebelum penambahan ekstrak etanol buah bisbul warna basis krim berwarna putih. Aroma atau bau yang dihasilkan adalah khas 
buah bisbul. Aroma yang dihasilkan krim ekstrak buah bisbul tergantung dari konsentrasi ekstrak yang ditambahkan dalam sediaan krim. Semakin tinggi konsentrasi ekstrak maka aroma yang dihasilkan semakin meningkat, dari ketiga formula yang paling kuat aroma khas bisbulnya yaitu formula 3 karena konsentrasi ekstrak yang ditambahkan ke dalam sediaan krim paling besar dibandingkan formula 1 dan 2.

Homogenitas. Berdasarkan pada pemeriksaan homogenitas ketiga krim sesuai dengan literatur yaitu homogen. Krim dinyatakan homogen apabila mempunyai tekstur yang tampak rata dan tidak menggumpal.

Hasil Uji pH Sediaan Krim. pH krim menurun seiring dengan meningkatnya konsentrasi ekstrak kental buah bisbul yang ditambahkan dalam sediaan krim. Hal tersebut dikarenakan ekstrak buah bisbul memiliki $\mathrm{pH}$ asam yaitu $\mathrm{pH}$ 3. Semakin banyak konsentrasi ekstrak buah bisbul yang ditambahkan maka semakin asam $\mathrm{pH}$ krim yang dihasilkan. Penurunan $\mathrm{pH}$ krim cenderung kecil karena kandungan asam dari ekstrak seperti flavonoid merupakan asam lemah sehingga hanya sebagian kecil terdisosiasi menjadi $\mathrm{H}^{+}$. Nilai $\mathrm{pH}$ pada sediaan krim yang diperoleh berkisar 6,55-7,05; sementara itu $\mathrm{pH}$ basis krim (kontrol -) adalah 8,00. Hal ini menunjukkan bahwa $\mathrm{pH}$ krim sesuai dengan standar mutu sediaan krim tabir surya yaitu, 4,5-8,0 meskipun kurang sesuai dengan $\mathrm{pH}$ kulit yaitu 4,5-7,0. Hasil yang dihasilkan diharapkan masih bisa diterima karena rentang $\mathrm{pH}$ nya tidak terlalu jauh. krim yang memiliki $\mathrm{pH}$ terlalu basa akan menyebabkan kulit bersisik sedangkan jika $\mathrm{pH}$ terlalu asam menimbulkan iritasi kulit ${ }^{(29)}$. Hasil pengujian $\mathrm{pH}$ dapat dilihat pada Gambar 1.

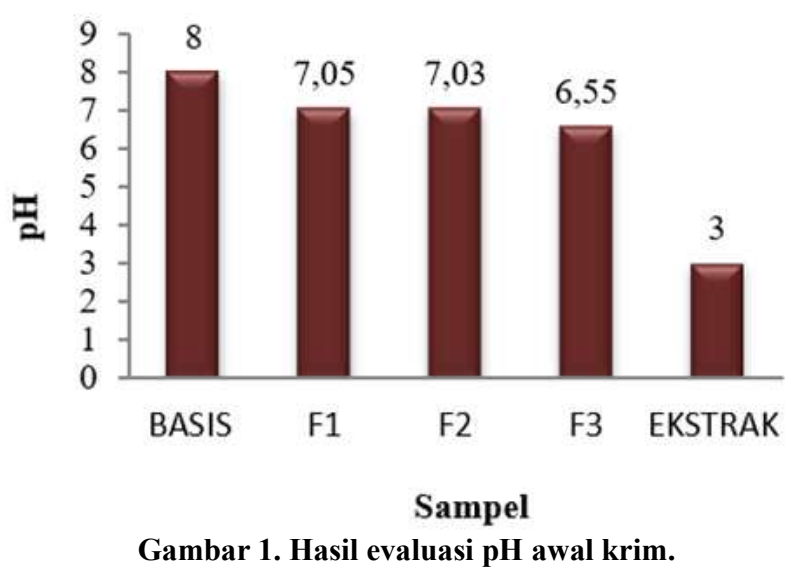

Hasil Uji Daya Sebar. Pengukuran daya sebar krim dilakukan dengan meletakan krim ditengahtengah kaca bulat. Kemudian, diukur diameternya selama satu menit lalu percobaan diulang dengan menambahkan beban seberat 50, 100, 150, dan 200 gram. Pengukuran daya sebar dilakukan sebanyak tiga ulangan. Hasil uji daya sebar dapat dilihat pada Tabel 6. Berdasarkan hasil rerata pada Tabel 6 maka dapat dibuat grafik hubungan beban krim yang digunakan dan hasil rerata daya sebar krim untuk mengetahui formulasi yang lebih baik daya sebarnya. Hubungan antara beban krim dan hasil rerata daya sebar dapat dilihat pada Gambar 2. Berdasarkan pada hasil pengujian diperoleh uji daya sebar pada F3 lebih luas penyebarannya dibandingkan dengan F1 dan F2. Hal disebabkan oleh tingkat kekentalan pada F1 dan F2 yang lebih kental dibandingkan dengan F3. Hal tersebut disebabkan karena viskositas F3 lebih rendah dibandingkan dengan F1 dan F2. Semakin tinggi viskositas krim semakin kecil daya sebarnya.

Tabel 6. Hasil uji daya sebar krim ekstrak buah bisbul.

\begin{tabular}{cccc}
\hline \multirow{2}{*}{$\begin{array}{c}\text { Beban } \\
(\mathrm{g})\end{array}$} & \multicolumn{3}{c}{ Hasil daya sebar $(\mathrm{cm})$} \\
\cline { 2 - 4 } & $\mathrm{F} 1$ & $\mathrm{~F} 2$ & $\mathrm{~F} 3$ \\
\hline & Rerata \pm SD & Rerata \pm SD & Rerata \pm SD \\
\hline 0 & $1,50 \pm 0,25$ & $1,32 \pm 0,09$ & $1,61 \pm 0,10$ \\
50 & $1,75 \pm 0,12$ & $1,55 \pm 0,04$ & $1,79 \pm 0,07$ \\
100 & $1,83 \pm 0,07$ & $1,75 \pm 0,12$ & $1,92 \pm 0,07$ \\
150 & $1,90 \pm 0,03$ & $1,91 \pm 0,03$ & $2,23 \pm 0,22$ \\
200 & $1,92 \pm 0,07$ & $2,25 \pm 0,25$ & $2,50 \pm 0,25$ \\
\hline
\end{tabular}

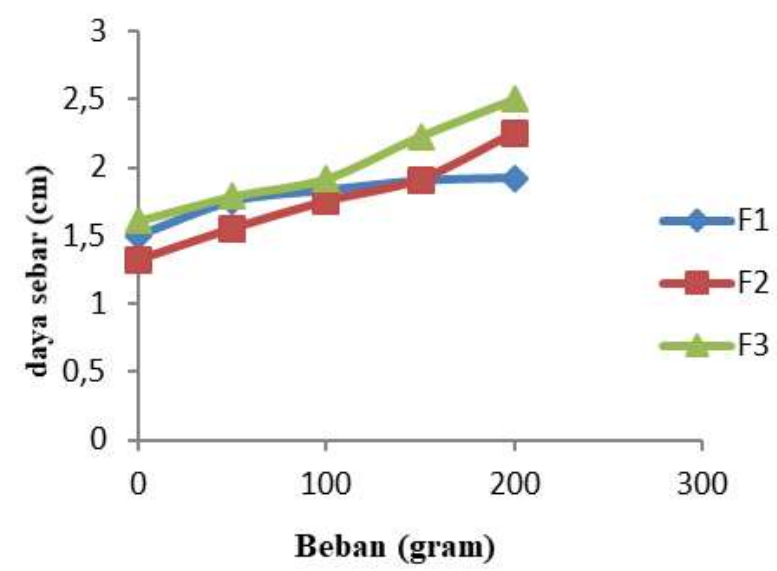

Gambar 2. Hubungan antara beban krim dan daya sebar krim.

Hasil Uji Daya Lekat. Pengujian daya lekat menggunakan dua buah kaca transparan yang pada salah satu ujung kaca ditekan beban 50 gram selama 5 menit, kemudian melepaskan beban seberat 20 gram dan dicatat waktunya hingga kedua kaca tersebut terlepas. Hasil rerata uji daya lekat dapat dilihat pada Tabel 7 (Gambar 3). Pengujian daya lekat dilakukan sebanyak 3 ulangan. Berdasarkan pada hasil pengujian semua formula sesuai dengan literatur waktu daya lekat yang baik, yaitu tidak kurang dari $4 \operatorname{detik}^{(30)}$. 
Tabel 7. Hasil uji daya lekat ekstrak buah bisbul.

\begin{tabular}{cc}
\hline Formula & Hasil daya lekat (detik) \\
\hline F1 & $86 \pm 15,27$ \\
F2 & $44 \pm 5,13$ \\
F3 & $11 \pm 3,60$ \\
\hline
\end{tabular}

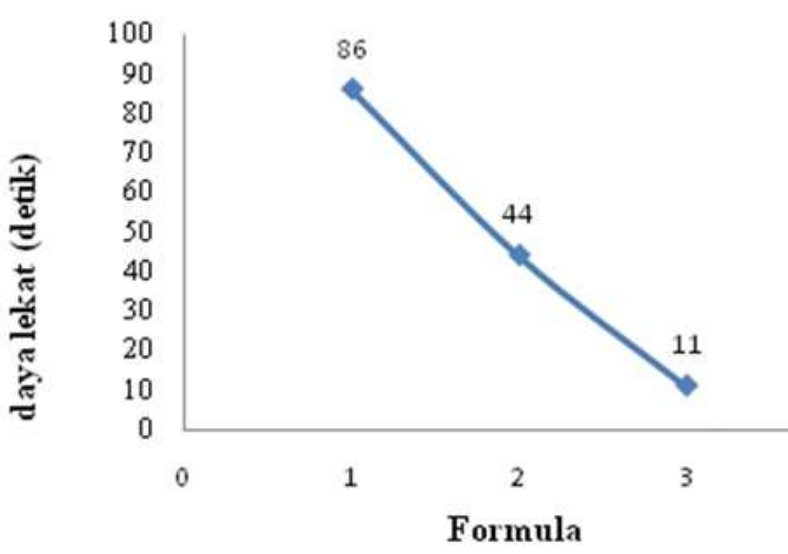

Gambar 3. Hubungan antara formula dan waktu daya lekat krim.

Hasil Cycling Test. Pengujian cycling test dilakukan pada hari ke-1 sediaan krim dibuat dengan cara sampel krim ekstrak buah bisbul disimpan pada suhu rendah $\left(4 \pm 2^{\circ} \mathrm{C}\right)$ selama 24 jam, lalu dipindahkan ke oven pada suhu $40 \pm 2 \mathrm{C}$ selama 24 jam, perlakuan ini adalah satu siklus. Percobaan diulang selama 6 siklus dan diamati adanya perubahan kondisi fisik krim pada kondisi awal dan setelah siklus ke-6. Hasil pengujian cycling test dapat dilihat pada Tabel 8 .

Berdasarkan pada uji cycling test didapatkan adanya perubahan kondisi fisik seperti warna dan aroma pada $\mathrm{F} 1$ dan adanya perubahan fisik krim seperti warna, aroma, dan homogenitas pada F2 dan F3. Hal tersebut disebabkan karena perubahan suhu penyimpanan yang tidak stabil menyebabkan kandungan dalam krim ekstrak buah bisbul terpisah dan warna menjadi lebih gelap dan aroma menjadi lebih kuat.

Hasil Uji Sentrifugasi. Pengujian ini bertujuan untuk mengetahui kestabilan fisik dari formula krim yang mengandung ekstrak buah bisbul dari konsentrasi 10, 20, dan $40 \%$. Pengujian sentrifugasi dilakukan pada hari ke-1 menggunakan sentrifugator. Sampel krim ekstrak buah bisbul dimasukkan ke dalam tabung sentrifugasi, kemudian dimasukkan ke dalam dalam sentrifugator dengan kecepatan putaran $3750 \mathrm{rpm}$ selama 5 jam. Berdasarkan hasil pengujian, ketiga krim stabil dan diharapkan stabil dalam penyimpanan 1 tahun dari efek gravitasi. Hasil pengujian dapat dilihat pada Tabel 9.

Tabel 9. Hasil uji sentrifugasi.

\begin{tabular}{ccc}
\hline \multirow{2}{*}{ Formula } & \multicolumn{2}{c}{ Hasil pengujian sentrifugasi } \\
\cline { 2 - 3 } & Awal & Akhir \\
\hline \multirow{2}{*}{ F1 } & Tidak terjadi & Tidak terjadi \\
& pemisahan & pemisahan \\
F2 & Tidak terjadi & Tidak terjadi \\
& pemisahan & pemisahan \\
F3 & Tidak terjadi & Tidak terjadi \\
& pemisahan & pemisahan \\
\hline
\end{tabular}

Hasil Uji Stabilitas Fisik Sediaan Krim. Uji stabilitas dilakukan dengan penyimpanan pada suhu rendah $\left(4 \pm 2{ }^{\circ} \mathrm{C}\right)$, suhu kamar $\left(28 \pm 2{ }^{\circ} \mathrm{C}\right)$, dan suhu tinggi $\left(40 \pm 2{ }^{\circ} \mathrm{C}\right)$. Pada uji ini dilakukan pengamatan organoleptik (warna, aroma, tekstur, dan homogenitas) dan $\mathrm{pH}$ selama 28 hari. Hasil pengamatan organoleptik dapat dilihat pada Tabel 10. Pengamatan dilakukan setiap minggunya. Pada masing-masing krim mengalami perubahan warna menjadi lebih kecoklatan pada penyimpanan di suhu $40 \pm 2{ }^{\circ} \mathrm{C}$ disebabkan oleh proses pemanasan. Sementara pada suhu rendah $\left(4 \pm 2^{\circ} \mathrm{C}\right)$ dan suhu kamar $\left(28 \pm 2{ }^{\circ} \mathrm{C}\right)$ tidak terjadi perubahan. Semakin besar konsentrasi ekstrak buah bisbul yang digunakan semakin menjadi tua warna krim setelah disimpan. Hal ini disebabkan karena suhu yang tinggi membuat polifenol (flavonoid) dalam ekstrak semakin mudah teroksidasi. Semakin banyak konsentrasi polifenol di dalam krim terlihat akibat dari proses oksidasinya yang ditandai dengan warna kecoklatan $^{(31)}$.

Pada pengamatan tekstur di penyimpanan suhu $40 \pm 2^{\circ} \mathrm{C}$, krim mengalami perubahan tekstur menjadi lebih cair karena proses pemanasan yang membuat krim menjadi kurang stabil. Pengamatan aroma pada semua suhu penyimpanan tidak begitu terjadi perubahan pada masing-masing krim. Hasil pengamatan $\mathrm{pH}$ dapat dilihat pada Tabel 11 .

Tabel 8. Hasil pengujian cycling test.

\begin{tabular}{|c|c|c|c|c|c|c|}
\hline \multirow{3}{*}{ Formula } & \multicolumn{6}{|c|}{ Hasil pengamatan fisik krim } \\
\hline & \multicolumn{3}{|c|}{ Sebelum } & \multicolumn{3}{|c|}{ Sesudah } \\
\hline & Warna & Aroma & Homogenitas & Warna & Aroma & Homogenitas \\
\hline F1 & Krem & Khas bisbul lemah & Homogen & Coklat muda & Stabil & Homogen \\
\hline $\mathrm{F} 2$ & Coklat muda & Khas bisbul sedang & Homogen & Coklat tua & Stabil & Homogen \\
\hline F3 & Coklat tua & Khas bisbul kuat & Homogen & Coklat tua & Stabil & Homogen \\
\hline
\end{tabular}


Tabel 10. Hasil pengamatan organoleptik pada variasi suhu penyimpanan.

\begin{tabular}{|c|c|c|c|c|c|}
\hline \multirow{2}{*}{ Formula } & \multirow{2}{*}{ Minggu ke- } & \multicolumn{4}{|c|}{ Pengamatan suhu rendah $\left(4 \pm 2^{\circ} \mathrm{C}\right)$} \\
\hline & & Warna & Aroma & Tekstur & Homogenitas \\
\hline \multirow{2}{*}{$\mathrm{F} 1$} & 1 & 1 & 1 & 1 & 1 \\
\hline & 4 & 1 & 1 & 1 & 2 \\
\hline \multirow{2}{*}{$\mathrm{F} 2$} & 1 & 1 & 1 & 1 & 1 \\
\hline & 4 & 1 & 1 & 1 & 2 \\
\hline \multirow{2}{*}{$\mathrm{F} 3$} & 1 & 1 & 1 & 1 & 1 \\
\hline & 4 & 1 & 1 & 1 & 2 \\
\hline \multirow{2}{*}{ Formula } & \multirow{2}{*}{ Minggu ke- } & \multicolumn{4}{|c|}{ Pengamatan suhu kamar $\left(28 \pm 2^{\circ} \mathrm{C}\right)$} \\
\hline & & Warna & Aroma & Tekstur & Homogenitas \\
\hline \multirow{2}{*}{$\mathrm{F} 1$} & 1 & 1 & 1 & 1 & 1 \\
\hline & 4 & 1 & 1 & 1 & 2 \\
\hline \multirow{2}{*}{$\mathrm{F} 2$} & 1 & 1 & 1 & 1 & 1 \\
\hline & 4 & 1 & 1 & 1 & 2 \\
\hline \multirow{2}{*}{$\mathrm{F} 3$} & 1 & 1 & 1 & 1 & 1 \\
\hline & 4 & 1 & 1 & 1 & 2 \\
\hline \multirow{2}{*}{ Formula } & \multirow{2}{*}{ Minggu ke- } & \multicolumn{4}{|c|}{ Pengamatan suhu tinggi $\left(40 \pm 2^{\circ} \mathrm{C}\right)$} \\
\hline & & Warna & Aroma & Tekstur & Homogenitas \\
\hline \multirow{2}{*}{$\mathrm{F} 1$} & 1 & 1 & 1 & 1 & 1 \\
\hline & 4 & 2 & 1 & 2 & 2 \\
\hline \multirow{2}{*}{$\mathrm{F} 2$} & 1 & 1 & 1 & 1 & 1 \\
\hline & 4 & 2 & 1 & 2 & 2 \\
\hline \multirow{2}{*}{$\mathrm{F} 3$} & 1 & 1 & 1 & 1 & 1 \\
\hline & 4 & 2 & 1 & 2 & 2 \\
\hline
\end{tabular}

\section{Keterangan}

Warna $\quad=1$ (tidak berubah), 2 (sedikit berubah)

Aroma $\quad=1$ (tidak berubah), 2 (sedikit berubah)

Tekstur $\quad=1$ (tidak berubah), 2 (sedikit berubah)

Homogenitas $=1$ (tidak berubah), 2 (sedikit berubah)

Tabel 11. Hasil pengamatan pH pada suhu rendah $\left(4 \pm 2^{\circ} \mathrm{C}\right)$, $\operatorname{kamar}\left(28 \pm 2^{\circ} \mathrm{C}\right)$, dan $40 \pm 2^{\circ} \mathrm{C}$.

\begin{tabular}{lcccccccccccc}
\hline \multirow{2}{*}{ Formula } & \multicolumn{3}{c}{$\begin{array}{c}\text { Suhu rendah } \\
\text { Minggu ke- }\end{array}$} & & \multicolumn{3}{c}{$\begin{array}{c}\text { Suhu kamar } \\
\text { Minggu ke- }\end{array}$} & \multicolumn{3}{c}{$\begin{array}{c}\text { Suhu tinggi } \\
\text { Minggu ke- }\end{array}$} \\
\hline & 1 & 2 & 3 & 4 & 1 & 2 & 3 & 4 & 1 & 2 & 3 & 4 \\
\hline F1 & 7,05 & 7,21 & 7,29 & 7,40 & 7,05 & 7,05 & 7,04 & 7,03 & 7,05 & 7,03 & 7,02 & 7,02 \\
F2 & 7,03 & 7,05 & 7,21 & 7,29 & 7,03 & 7,03 & 7,02 & 7,00 & 7,03 & 6,99 & 6,88 & 6,75 \\
F3 & 6,55 & 6,88 & 6,91 & 6,91 & 6,56 & 6,56 & 6,55 & 6,55 & 6,55 & 6,55 & 6,54 & 6,54 \\
\hline
\end{tabular}

Berdasarkan hasil pengamatan pada penyimpan di suhu $4 \pm 2^{\circ} \mathrm{C}$, krim mengalami kenaikan $\mathrm{pH}$ menjadi lebih basa dikarenakan pada suhu rendah reaksi hidrolisis yang terjadi dapat dicegah sehingga $\mathrm{pH}$ krim tidak mengalami penurunan seperti krim pada penyimpanan di suhu kamar dan suhu $40 \pm 2^{\circ} \mathrm{C}$. Pada dua kondisi penyimpanan tersebut, reaksi hidrolisis antara polifenol (flavonoid) dengan glikosida terjadi lebih cepat sehingga polifenol terlepas dari glikosidanya dan terdapat dalam bentuk bebas yang lebih asam. Semakin besar konsentrasi ekstrak buah bisbul maka $\mathrm{pH}$ yang dihasilkan semakin asam karena kandungan polifenol / flavonoid ${ }^{(31)}$.

Stabilitas Viskositas Sediaan Krim. Pengukuran viskositas dilakukan menggunakan viskometer Brookfield MLVT 115 pada spindel 4 dengan kecepatan $30 \mathrm{rpm}$. Faktor koreksi untuk spindel 4 adalah 200. Viskositasnya (cps) adalah angka hasil pengukuran $\mathrm{x}$ faktor koreksi. Pengukuran viskositas dilakukan pada minggu ke-1 dan minggu ke-3.

Berdasarkan pada hasil pengujian, viskositas krim mengalami penurunan dari minggu ke-1 karena sifat 
ekstrak buah bisbul yang higroskopik atau menyerap molekul air dari lingkungannya sehingga volume air dalam krim meningkat. Semakin besar konsentrasi ekstrak dalam krim dan semakin lama penyimpanan, maka viskositas krim akan semakin cair. Selain itu semakin banyak fase air dalam krim mempengaruhi viskositas krimnya pula. Berdasarkan pada hasil pengukuran yang telah dilakukan, ketiga krim pada minggu ke-1 dan minggu ke-3 sesuai dengan viskositas krim yang baik, yaitu $2000-50000 \mathrm{cps}$. Hasil pengamatan viskositas dapat dilihat pada Gambar 4

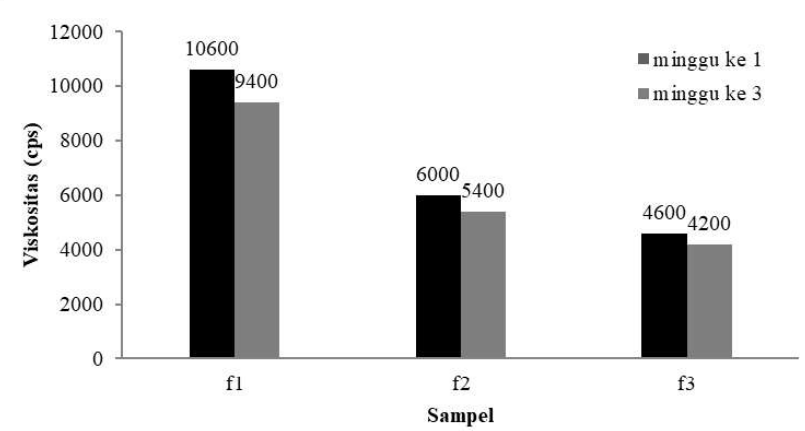

Gambar 4. Hasil viskositas krim pada minggu ke-1 dan ke-3.

Nilai SPF Sediaan Krim. Pengujian nilai SPF dilakukan dengan menggunakan spektrofotometer UV-Vis Shimadzu UV mini-1240V dengan rentang panjang gelombang 290-320 nm. Hal yang pertama dilakukan yaitu menimbang sebanyak 0,1 gram masing-masing sampel kemudian dilarutkan dalam etanol $96 \%$ sebanyak $25 \mathrm{~mL}$ dan dicampur hingga homogen kemudian diukur serapannya. Sebelumnya spektrofotometer UV-Vis dikalibrasi dengan menggunakan etanol 96\%. Hasil dari uji nilai SPF dapat dilihat pada Tabel 12.

Tabel 12. Hasil pengujian nilai SPF.

\begin{tabular}{ccc}
\hline Sampel & Nilai SPF & $\begin{array}{c}\text { Kategori } \\
\text { Proteksi }\end{array}$ \\
\hline Ekstrak & $36,02 \pm 0,42$ & Ultra \\
Basis krim & $1,60 \pm 0,08$ & - \\
F1 & $9,26 \pm 0,63$ & Maksimal \\
F2 & $10,02 \pm 0,00$ & Maksimal \\
F3 & $13,00 \pm 0,12$ & Maksimal \\
\hline
\end{tabular}

Berdasarkan hasil pengukuran yang telah dilakukan, ekstrak buah bisbul memiliki nilai SPF sebesar 36,02 yang berarti memiliki kemampuan ultra sebagai tabir surya. Pada F1, F2, dan F3 masingmasing memiliki nilai 9,26; 10,02; dan 13,00. Dari ketiga formula F3 memiliki nilai SPF tinggi yaitu sebesar 13,00 yang memiliki kemampuan maksimal sebagai tabir surya, sedangkan pengujian yang dilakukan pada basis krim tanpa ekstrak sebesar
1,60 yang tidak memiliki kemampuan sebagai tabir surya. Hal tersebut menunjukkan basis krim tidak memberikan pengaruh terhadap nilai SPF formula sehingga semakin besar konsentrasi yang ditambahkan pada sediaan krim maka semakin besar nilai SPF yang didapat.

Hubungan Nilai SPF dengan Nilai $\mathrm{IC}_{50}$. Buah bisbul memiliki salah satu kandungan terpenting yaitu flavonoid yang berperan sebagai antioksidan dan berguna sebagai bahan aktif tabir surya ${ }^{(31)}$. Berdasarkan pada hasil penelitian didapat aktivitas antioksidan dan nilai SPF menunjukkan adanya hubungan. Semakin besar aktivitas antioksidannya maka semakin besar nilai SPF krim. Hasil nilai SPF dan nilai $\mathrm{IC}_{50}$ dapat dilihat pada Tabel 13.

Hasil Analisis Data. Berdasarkan pada analisis

Tabel 13. Hasil pengujian nilai SPF.

\begin{tabular}{ccc}
\hline Sampel & SPF & $\mathrm{IC}_{50}(\mathrm{bpj})$ \\
\hline F1 & $9,25 \pm 0,63$ & 4802,63 \\
F2 & $10,02 \pm 0,00$ & 3510,11 \\
F3 & $13,00 \pm 0,12$ & 638,32 \\
Ekstrak & $36,02 \pm 0,42$ & 69,13 \\
\hline
\end{tabular}

data yang dilakukan semua data yang diuji terdistribusi normal $(\mathrm{p}>0,05)$. Kemudian, dilakukan uji satu arah Anova dengan taraf kepercayaan $95 \%$. Data yang diuji yaitu aktivitas tabir surya, daya sebar, daya lekat, dan viskositas. Berdasarkan pada uji tersebut semua data adanya pengaruh yang signifikan antara setiap formula terhadap aktivitas tabir surya, daya sebar, daya lekat, dan viskositas krim $(\mathrm{p}<0,05)$.

Selanjutnya, data aktivitas tabir surya dilakukan uji lanjutan uji BNT (beda nyata terkecil) untuk mengetahui ada atau tidaknya perbedaan aktivitas krim tabir surya secara bermakna pada setiap formula. Berdasarkan pada uji tersebut dapat disimpulkan bahwa aktivitas krim tabir surya setiap formula uji berbeda secara bermakna dengan basis krim dan ekstrak $(\mathrm{p}<0,05)$.

\section{SIMPULAN}

Kandungan fitokimia ekstrak etanol 95\% buah bisbul terdiri atas alkaloid, saponin, flavonoid, tanin, fenolik, triterpenoid, dan glikosida. Formula sediaan krim dengan kandungan ekstrak buah bisbul $40 \%$ memiliki nilai SPF tertinggi sebesar 13,0. Krim memiliki kestabilan yang baik pada penyimpanan suhu rendah $\left(4 \pm 2^{\circ} \mathrm{C}\right)$ dan $\operatorname{kamar}\left(28 \pm 2^{\circ} \mathrm{C}\right)$ berdasarkan pada nilai $\mathrm{pH}$, viskositas, organoleptik, daya sebar, dan daya lekat. 


\section{DAFTAR PUSTAKA}

1. Yulianti E, Adelsa A, Putri, A . Penentuan nilai SPF (sun protection factor) ekstrak etanol 70\% temu mangga (Curcuma mangga) dan krim ekstrak etanol $70 \%$ temu mangga (Curcuma mangga) secara in vitro menggunakan metode spektrofotometri. Majalah Kesehatan FKUB. 2015; 2(1):41-50.

2. Shovyana HH, Zulkarnain AK. Stabilitas fisik dan aktivitas krim $W / O$ ekstrak etanolik buah mahkota dewa (Phaleria macrocarpha (Scheff.) Boerl,) sebagai tabir surya. Trad. Med. J. 2013;18(2):109-17.

3. Damogalad V, Edy HJ, Supriati HS. Formulasi krim tabir surya ekstrak kulit nanas (Ananas winosus L MERR) dan uji in vitro sun protecting faCtor (SPF). Pharmacon. 2013; 2(2): 39-43.

4. Rejeki S, Wahyuningsih SS. Formulasi gel tabir surya minyak nyamplung (Tamanu Oil) dan uji nilai SPF secara in vitro. University Research Colloquim. 2015; 97-103.

5. Subchan P, Malik DA, Namason WT. Fotoproteksi. MDVI. 2011. 38(3):141-8.

6. Retnaningsih C, Darmono, Widianarko, B, Muis, SF. Peningkatan aktivitas antioksidan superoksida dismutase pada tikus hiperglikemi dengan asupan tempe koro benguk (Mucuna pruriens L.). Agritech. 2013; 33(2):154-161.

7. Ayuningrum. Uji stabilitas fisik dan penentuan nilai SPF (sun protection factor) krim tabir surya ekstrak kulit buah pepaya (Carica papaya L.).[Artikel]. Ungaran: Sekolah Tinggi Kesehatan Ngudi Waluyo Ungaran. 2016.

8. Kementerian Kesehatan RI. Farmakope Indonesia Edisi Lima. Jakarta: KemenKes RI. 2014.

9. Kementerian Kesehatan RI. Formularium Nasional. Jakarta: KemenKes RI. 2015.

10. Juwita AP, Yamlean PVY, Edy HJ. Formulasi krim ekstrak etanol daun lamun (Syringodium isoetifolium). Pharmacon. 2013; 2(2):8-12.

11. Departemen Kesehatan RI. Farmakope Herbal Indonesia Edisi I. Jakarta: DepKes RI. 2013.

12. Molyneux P. The use of the stable free radical diphenilpicryl-hydrazyl (DPPH) for estimating antioxidant activity. Songklanakarin J. Sci. Technol. 2004; 26(2):212-6.

13. Departemen Kesehatan RI. Formularium Kosmetika Indonesia (Cetakan I). Jakarta: DepKes RI. 1985.

14. Agustin R, Defitri YO, Lucida H. Formulasi krim tabir surya dari kombinasi etil p-metoksisinamat dengan katekin. Dalam Seminar Nasional Perkembangan Terkini Sains Farmasi dan Klinik III. 2013; 184-97.

15. Nova. Formulasi ekstrak metanol kulit manggis (Garcinia mangostana L) pada uji iritasi primer [skripsi].Yogyakarta. Fakultas Farmasi Universitas Sanata Dharma Yogyakarta. 2012.

16. Safitri NA, Puspita OK, Yurina V. Optimasi formula sediaan krim ekstrak stroberi (Fragaria $\mathrm{x}$ ananssa) sebagai krim anti penuaan. Majalah Kesehatan FKUB. 2014; 1(4):235-40.
17. Budiarti TK. Aktivitas antioksidan dari buah bakau (Rhizophora mucronata Lamk.) pada formulasi skin lotion dengan karaginan [skripsi]. Bogor: Fakultas Perikanan dan Ilmu Kelautan Institut Pertanian Bogor. 2014.

18. Nurdianti L, Rahmiyani I. Uji aktivitas antioksidan krim ekstrak daun mangga (Mangifera indica $\mathrm{L}$ ) terhadap DPPH (1,1-Dipenyl-2-Picrylhydrazil). Jurnal Kesehatan Bakti Tunas Husada. 2016; 16(1):49-52.

19. Bulan AS, Susanti L, Pranata W. Formulasi ekstrak buah jambu biji sebagai lotion antioksidan. Jurnal Farmasi Indonesia. 2014; 11(1):38-41.

20. Sharon N, Anam S, Yuliet. Formulasi krim antioksidan ekstrak etanol bawang hutan. Online Jurnal of Natural Science. 2013; 2(3):111-22.

21. Wihelmina. Pembuatan dan penentuan nilai SPF nanoemulsi tabir surya menggunakan minyak kencur (Kaempferia galanga L.) sebagai fase minyak [skripsi]. Jakarta: Universitas Indonesia. 2011.

22. Mokodompit AN, Edy HJ, Wiyono W. Penentuan nilai sun protective factor (SPF) secara in vitro krim tabir surya ekstrak etanol kulit alpukat. Pharmacon. 2013; 2(3): 84-5.

23. Sayre RM, Agin PP, Levee GJ, Marlowe E. A comparison of in vivo and in vitro testing sunscreening formulas. Photo Chem. Photo Bial.1979.;29(3):55966.

24. Alhabsyi DF, Edi S, Wewengkang DS. Aktivitas antioksidan dan tabir surya pada ekstrak kulit buah pisang goroho (Musa acuminata L). Pharmacon. 2014; 3(2):107-14

25. Daud NS, Al Hajri NS, La Ode Z, Ervianingsih. Formulasi lotion tabir surya ekstrak etanol beras merah (Oryza nivara). Jurnal Ilmiah Ibnu Sina. 2016; 1(2): 143-57.

26. Departemen Kesehatan RI. Materia Medika indonesia, Edisi III. Direktorat Pengawasan Obat dan Makanan. Jakarta: DepKes RI. 1979.

27. Harliany D, Taufiqurrohman I, Dewi N. Uji variasi konsentrasi pelarut etanol terhadap kadar total flavonoid ekstrak daun ramania (Bouea macrophylla Griffith). Dentino Jurnal Kedokteran Gigi. 2017.;1(1):1-5.

28. Widyastuti, Fratama RI, Seprialdi A. Pengujian aktivitas antioksidan dan tabir surya ekstrak etanol kulit buah naga super merah (Hylocereus costaricensis (F.A.C. Weber) Britton \& Rose). Scientia. 2015; 5(2): 69-73.

29. Mu'awanah, Isnin AU, Setiaji B, Syoufia A. Pengaruh kosentrasi virgin coconut oil (VCO) terhadap stabilitas emulsi kosmetik dan nilai sun protection factor (SPF). Berkala MIPA. 2014; 24(1): 5-6.

30. Zam UAZ, Sutaryono, Yetti OK. Formulasi krim ekstrak etanol buah strawberry (Fragaria Sp.). Cerata Journal of Pharmacy Science. 2013;4(1):1-12

31. Setiawan T. Uji stabilitas fisik dan penentuan nilai SPF krim tabir surya yang mengandung ekstrak daun teh hijau (Camellia Sinensis L) oksil metoksisinamat dan titanium dioksida [Skripsi]. Depok: FMIPA Universitas Indonesia. 2010. 